\title{
BENIGN HAMARTOMA OF THE LIVER
}

\author{
BY \\ R. E. REWELL \\ From the Government Hospital for Women and Children, Egmore, Madras
}

(RECEIVED FOR PUBLICATION SEPTEMBER 10, 1956)

Sheehan (1930) when describing a malignant liver tumour in a young child, first brought together a number of such tumours previously described under a variety of names, such as 'sarcoma', 'endothelioma' or 'angeiosarcoma', and pointed out that they were probably all derived from rests of undifferentiated mesenchymal cells and were in fact embryonic growths. The tumour he described consisted largely of undifferentiated mesenchyme forming cysts lined with bile-duct epithelium, but in one cyst the basic cells showed malignant features with vascular invasion. In other places they had differentiated into myxoma, fibrous tissue, acinar tissue and striated muscle.

These tumours are evidently rare and few later reports are available (e.g., Nissel, 1928; Roth, 1938; Webster, 1938; Wells, 1940; McRae, 1935). All appear to accept an embryonic origin for the tumours and, indeed, Roth termed his a 'unilayered teratoma'. All the tumours so far reported appear to have been malignant with multiple vascular metastases within

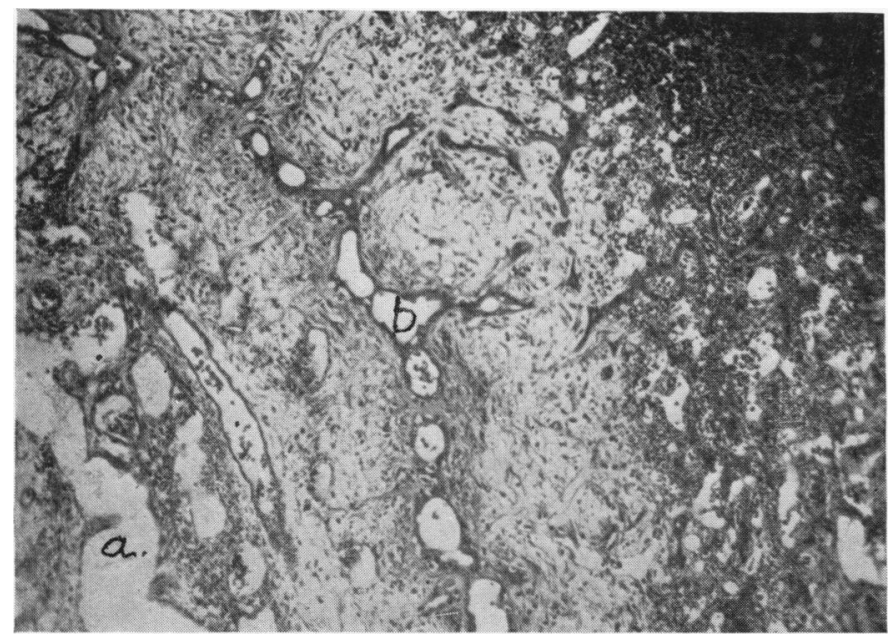

Fig. 1.-Section of tumour from near its pedicle showing vascular channels on the left (a), tubes of bile duct epithelium in the middle (b) and well-formed liver parenchyma to the right, the whole filled in by loose mesenchymal tissue $(\times 88)$. the liver but a curious absence of metastases to other sites.

\section{Case Record}

A girl aged 18 months was brought to hospital by her mother who had noticed swelling of the child's abdomen for about six months. The child appeared perfectly fit apart from the obvious swelling, which was due to a firm, smooth, solid tumour filling most of the abdomen and whose origin could not be determined clinically. There appeared to be nothing relevant in the family history and the child was the result of a normal pregnancy and delivery.

At laparotomy an enormous, smooth tumour was found suspended from the under surface of the liver by a narrow pedicle and was removed without undue difficulty. The remaining abdominal viscera appeared superficially normal. The child made an uninterrupted recovery.

The gross tumour was ovoid, about $30 \mathrm{~cm} . \times 30 \mathrm{~cm} . \times$ $20 \mathrm{~cm}$., with a smooth surface covered by peritoneum and with no obvious adhesions. The cut surface showed many small cysts of up to $1 \mathrm{~cm}$. across and containing colourless, gelatinous material. The intervening substance appeared homogeneous and of a deep red colour and was quite firm.

Histology. A number of blocks were taken from different areas, but all showed a very similar, fundamentally an identical, picture, except that there was more normal liver tissue in the blocks taken from near the pedicle than was found elsewhere. There were then islands of normal, perfectly-differentiated liver tissue. Most of the tumour, however, consisted of ramifying bile ducts, or rather, since they had no muscular coats, tubes of bile duct epithelium. They were of all sizes and the cysts appeared to be dilatations of them. No malignant features were found in the epithelium in the numerous blocks taken. The second type of tissue consisted of numerous, thin-walled vascular channels, which, however, were well developed and showed no malignant features, although in places they were so 
closely crowded as to resemble a cavernous haemangioma. No other type of blood-vessel-forming tissue was seen and it was evident that the tumour was not fundamentally any type of true angioma. The third, and most obvious, element in the tumour was loose-textured connective tissue. Once more, this was perfectly well differentiated and no malignant features were seen. However, this tissue was very great in amount and evidently constituted an essential part of the tumour and could not be regarded as a mere supporting framework. All these features are shown in Fig. 1.

\section{Discussion}

In the tumour described, all the tissue elements were perfectly differentiated in all areas examined, no stages in this differentiation were seen, and all the elements were such as can be found in the mature liver. It becomes, therefore, a matter of definition whether or not it fits Sheehan's conception of the origin of similar tumours from undifferentiated mesenchymal cells. Most of the other tumours described have contained other tissues which are not normally present in the developed liver, e.g., Sheehan's tumour which contained striped muscle. However, all these other tumours showed malignant features, i.e., their cells, or at least some of them, had not differentiated fully. It would appear, then, that the present one must either be regarded as taking its origin from mesenchymal cells better differen- tiated than those which caused the other tumours or as arising from four different tissues after they had become differentiated. The former theory places less strain on the imagination.

The present writer has always been sceptical of the existence of hypothetical 'undifferentiated' cells whose existence can only be inferred by what is supposed to have developed from them, at any rate when dealing with adult tissues outside the gonads. The mass found in this child's liver contains adulttype tissues, fully-differentiated, but in abnormal proportions. It would seem best, therefore, to describe it as a 'hamartoma', a term which implies no theory of its origin.

\section{Summary}

Another of the very rare embryonic tumours of the liver is reported. It contained well differentiated tissues and was benign. Most of those described previously have been malignant in some part. The present example is probably best classified as an hamartoma.

\section{REFERENCES}

McRae, F. W. (1935). Amer. J. Surg., 28, 575.

Nissel, W. (1928). Virchows Arch. path. Anat., 269, 446.

Roth, F. (1938). Frankfurt. Z. Path., 52, 163.

Sheehan, H. L. (1930). J. Path. Bact., 33, 251.

Webster, R. (1938). Med. J. Aust., 2, 381.

Wells, H. G. (1940). Arch. Path. (Chicago), 30, 535. 